the other. At the present moment there were on the staffs of the London hospitals no less than seven former pupils, and during the last few years 14 open scholarships at the University had been won by boys from Epsom College.

\section{THE HOSPITAL FOR SICK CHILDREN.}

In securing for the second year in succession a member of the Royal Family to preside at their anniversary festival the Committee of theHospital for Sick Children in GreatOrmond Street were peculiarly favoured. This year's function took place on Friday in last week at the Hotel Metropole, and among the company assembled under the presidency of the Duke of CAMBRIDGE were: His Grace the Duke of Fife, the Bishop of Bath and Wells, the Right Hon. Lord Kinnaird, Lord Monkswell, Sir R. Quain, Bart., M.D., Dr. Barlow, and Mr. Adrian Hope (secretary).

The preliminaries having been somewhat quickly disposed of, the toast of "Prosperity to the Hospital for Sick Children" was submitted by the ChaIrman. He had visited the hospital, and was able to vouch that he had never been in an institution so clean, so well organised, and so well arranged. Everything he saw reflected the greatest credit on the management, the nurges, and the medical officers, and he was sure the money spent on that valuable and useful institution was wisely spent. Referring to the progress made by the hospitul, the Duke mentioned that the in-patients had increased from 1,281 in 1892 , to 1,678 in 1894 , and the outpatients from 21,045 to 27,334 . Coupled with the toast was the name of the President of the hospital.

The Duke of Fire, in responding, said there was no good and useful cause in this country which the chairman was not ready to assist, and he thanked him for the very prompt and willing manner in which he consented to take the chair that evening. There were many good causes in this country that enlisted sympathy and help, but there were none more deserving than the Hospital for Sick Children, for while other sufferers could help themselves a sick child was peculiarly helpless and dependent upon others. One of the best friends of the hospital was Charles Dickens. He took the chair at the first dinner (in 1858), and certainly no one in the whole branch of literature had ever described in more eloquent or touching words the needs and the wants and the suffering of little children; and the most pathetic and powerful appeal ever made in aid of that hospital came from the great novelist, whose name ought to be cherished by every child in this country. (Applause.)

Lord MonksweLL, as a member of four classes who were presumed to be able to speak on any subject at any time to any person, viz., politicians, peers, barristers, and county councillors, supposed it was on that assumption he was asked to take charge of the toast of "The Committee of Management." Coupled with it was the name of Mr. Arthur Lucas, the chairman of the committee, and Lord Monkswell testified to the able manner in which Mr. Lucas gave evidence before the House of Lords' Committee on Metropolitan Hospitals. Every member of the committee felt that he was so imbued with all the details of hospital management that he must have given an immense amount of time and labour to the duties he was called upon to discharge.

Mr. LuCAS, in his reply, took occasion to thank the chairman on behalf of the committee for coming there that night, und said it was generally known that the Duke, when he was invited had slosed the list of charities he intended to attend this season, but reopened it and included that hospital. After giving some statistics of the work of the hospital last year Mr. Lucas mentioned that at one time a fourth of the staff was incapacitate $\tilde{d}$ by influenza. The remainder of the staff, however, stuck to their work well, and they never had to refuse a single patient. (Hear, hear.)

The toast of the "Medical Officers" was submitted by the Bishop of BATH and WeLLS, who drew particular attention to the fact that only 245 deaths took place last year among the 1,671 in-patients. Dr. Edmund Owen replied. Some time since, he said, there was a boy in the hospital from whom the house-surgeon had to remove every morning a painful dressing, and every morning the boy cried. "Why cry?" the nurse asked, and the boy replied, "I know it must be done, but if I cry it makes the doctor more careful." (Laughter.) As a matter of fact they dealt with all those children as if the patient's eyes were brimming over with pathetic tears. They dealt with the sick children exactly as in similar circumstances they would like their own dear ones to be dealt with. (Applause.)

The proceedings closed with the announcement from the secretary of contributions to the extent of $£ 2,132$.

\section{PRACTICAL POINTS.}

Hospital Floors.-Could anyone through your valuable paper advise me what to do for a corridor of an hospital that is boarded in blocks, and is splitting in various places - the boards are very soft-the more it is scrubbed the worse it gets? Our hospital is badly off for funds, so cannot lay out much expense. It is a new hospital, and I cannot understand the boards wearing like this.

If this is a wood block floor laid on concrete the work must have been very badly done. For the rough wear of a corridor wood is unsuitable. The best thing to be done is to remove the wood and substitute artificial stone or terrazzo. If, however, this is quite out of the question, possibly the joints might be caulked (by a ship's joiner) with oakum and marine-glue. In any case, the floors should be treated with paraffin ironed in, hand-rubbed with oil and beeswax, washed as little as possible, but wiped over and dried when necessary. If the floor is boarded on joists, caulking and paraffining as above may help it; but soft wood is the worst material for hospital floors, and in the case in question, the more the floors are washed the more they will swell and shrink.

\section{EDITOR'S LETTER-BOX.}

「Our correspondents are reminded that proxility is a great bar to publi. oation, and that brevity of style and conoiseness of statement greatly facilitate early insertion.]

\section{AN EXCRETA CAGE.}

Mr. Newton H. Nixon, Secretary of University College Hospital, writes: I have read your article in THE HospitaL of the 18th inst. upon the new Adelaide Hospital, and in which the following paragraph occurs: "The construction of a ventilated 'fæcal cupboard' is the result of a suggestion made by Professor Allen, of Melbourne University, and is, we may assume, a practical outcome of his recent visit to English hospitals." I would venture to point out that the first "fæcal cupboard" in use in England was erected in this hospital upon my suggestions and drawings, and a cupboard is now attached to each sanitary block. The invention was exhibited by Messrs. Mayer and Meltzer, of Great Portland Street, at the International Medical and Sanitary Congress in 1882, where it was awarded a Certificate of Merit, and also at the National Health Society's Exhibition, 1883, when a Silver Medal was awarded.

** We agree with Mr. Nixon that most probably Professor Allen adopted his invention of a ventilated excreta cage, a most favourable notice of which appeared in our columns on its introduction.--ED. $T$. $H$.

\section{SCRAPS AND GLEANINGS}

A BACTERIOLOGICAL institation is about to be erected at Leicester. The local medical officer of health will direct the same.

THE Leper Hospital of St. Stephen's, in the Oounty of Waterford (Ireland) is to be converted into a county infirmary.

DoNATIONS to the extent of $£ 2,131$ are announced to have been received at the festival dinner of the Hospital for Sick Ohildren, Great Ormond Street.

THE report of the Royal Commission on tubereulosis, to which we have previously referred, is now effected, and was arranged to be definitely presented to Parliament last week.

"Physicienne" has been suggested by a weekly contemporary as a title for female members of the medical profession as being a more euphonions designation than lady doctor.

At the opening of the St. Mary's Hospital bazaar at Portman Rooms on June 27th by the Princess of Wales, she will be conducted through the bazaar by the Duke of York as president of the hospital.

THE date of the opening of the bazaar in aid of the Poor Sick Ohil. dren's Seaside Holiday Fund by the Countess Oadogan at the Queen's Gate Hall has been altered from the 27 th to the 26 th June.

THERE is an actual decrease of 2200 ou the voluntary contributions towards the Bath Mineral Waters Hospital this year. Considering the very large number of London poor sent here annually, the committee comment on the fact that the Metroplitan Hospital Sunday Fund have not awarded any contribution this year to their institation. 